Diabetologia (1994) 37: 871-878

\title{
Mechanisms underlying the insulinostatic effect of peptide YY in mouse pancreatic islets
}

\author{
A.G. Nieuwenhuizen, S. Karlsson, T. Fridolf, B. Ahrén \\ Department of Medicine, University of Lund, Malmö General Hospital, Malmö, Sweden
}

\begin{abstract}
Summary Peptide YY is an insulinostatic peptide which is released into the circulation from the intestinal mucosa upon food intake. Peptide YY is also co-stored with glucagon in the secretory granules of the pancreatic alpha cells. We examined the mechanisms underlying the insulinostatic effect of peptide $Y Y$ in isolated mouse pancreatic islets. We found that peptide $\mathrm{YY}(0.1 \mathrm{nmol} / \mathrm{l}-1 \mu \mathrm{mol} / \mathrm{l})$ inhibited glucose $(11.1 \mathrm{mmol} / \mathrm{l})$-stimulated insulin secretion from incubated isolated islets, with a maximal inhibition of approximately $70 \%$ observed at a dose of $1 \mathrm{nmol} /$ $1(p<0.001)$. Also in perifused islets the peptide $(1 \mathrm{nmol} / \mathrm{l})$ inhibited insulin secretion in response to $11.1 \mathrm{mmol} / 1$ glucose $(p<0.001)$. Furthermore, peptide YY inhibited glucose-stimulated cyclic AMP formation (by $67 \%, p<0.05$ ), and insulin secretion stimulated by dibutyryl cyclic AMP $(p<0.01)$. In contrast, the peptide was without effect both on the cytoplasmic $\mathrm{Ca}^{2+}$ concentration in dispersed mouse isletcell suspensions as measured by the FURA 2-AM technique, and on insulin release in isolated islets,
\end{abstract}

when stimulated by the protein kinase $\mathrm{C}$-activator 12-O-tetradecanoyl phorbol 13-acetate. Finally, in pre-labelled perifused islets, peptide YY caused a small and transient increase in the ${ }^{86} \mathrm{Rb}^{+}$efflux $(p<0.001)$, but only in the absence of extracellular $\mathrm{Ca}^{2+}$. We conclude that peptide YY inhibits glucosestimulated insulin secretion from isolated mouse islets by inhibiting two different steps in the cyclic AMP cascade, that is, both the accumulation and the action of the cyclic nucleotide. In contrast, the data suggest that protein kinase $\mathrm{C}, \mathrm{K}^{+}$channels, the cytoplasmic $\mathrm{Ca}^{2+}$ concentration or other processes directly regulating the exocytosis are not involved in the signal transduction underlying peptide YY-induced inhibition of insulin secretion. [Diabetologia (1994) 37: 871-878]

Key words Insulin secretion, beta cells, cytoplasmic calcium, potassium channels, protein kinase C, cyclic AMP, peptide YY.
Peptide YY (PYY) is a 36-amino acid peptide, which was initially found to be localized in mucosal endocrine cells of the terminal ileum and colon [1], and more recent results have shown that PYY is also an enteric neuropeptide [2]. The peptide shows structur-

Received: 13 December 1993

and in revised form: 13 April 1994

Corresponding author: Dr. S. Karlsson, Department of Medicine, Malmö General Hospital, S-21401 Malmö, Sweden

Abbreviations: PYY, Peptide YY; TPA, 12-O-tetradecanoylphorbol 13-acetate. al homology to pancreatic polypeptide and neuropeptide Y [3], both of which are regulatory peptides influencing insulin secretion among other processes $[4,5]$. Recently, PYY has been localized to the alpha cells in both the mouse and the rat pancreas $[6,7]$, where it is co-stored with glucagon in the secretory granules [8]. The peptide has previously been demonstrated to inhibit stimulated insulin secretion under in vivo conditions in the rat [9], dog $[10,11]$ and mouse [8], and in vitro in the perfused isolated rat pancreas and in isolated rat islets [12]. This suggests that PYY participates in the regulation of insulin secretion.

In the present study, we have examined possible mechanisms underlying the inhibitory effect of PYY 
on insulin secretion. Our study focused on well-established beta-cell signal transduction pathways. It is well known that several ion channels in the beta-cell plasma membrane, in particular voltage-dependent $\mathrm{Ca}^{2+}$ and ATP-regulated $\mathrm{K}^{+}$channels $[13,14]$, are crucial for the stimulus-secretion coupling of insulin secretion. Also, protein kinase C and cyclic AMP are intracellular modulators of insulin secretion $[13,15]$. We have studied, in normal mouse islets and dispersed mouse islet cells, the influences of PYY on 1) $\mathrm{K}^{+}$permeability (by means of ${ }^{86} \mathrm{Rb}^{+}$efflux), 2) the content and action of cyclic AMP, 3) protein kinase $\mathrm{C}$-dependent insulin secretion and 4) the cytoplasmic $\mathrm{Ca}^{2+}$ concentration.

\section{Materials and methods}

Animals. The experiments were performed in 6-8-week-old female mice of the NMRI strain (Laboratory Animals Breeding, Laven, Denmark), weighing 25-35 g. The animals had free access to a standard pellet diet (protein $21 \%$, fat $5 \%$, carbohydrates $51.5 \%$, fibres $3.5 \%$, ashes $7 \%$, water $12 \%$ ) (Lactamin AB, Vadstena, Sweden) and tap water before the experiments.

Isolation of islets. Pancreatic islets were isolated by the collagenase digestion technique described by Lacy and Kostianorsky [16] with slight modification. In short, animals were anaesthetised with sodium-pentobarbital $(120 \mathrm{mg} / \mathrm{kg}$; Apoteksbolaget, Umeå, Sweden). A catheter was inserted in the common bile duct, the duodenal papilla was occluded and the pancreas was retrogradely filled with $3 \mathrm{ml}$ ice-cold Hanks balanced salts solution (Sigma Chemical Co., St. Louis, Mo., USA) containing $0.3 \mathrm{mg} / \mathrm{ml}$ of collagenase (Collagenase P, Boehringer Mannheim $\mathrm{GmbH}$, Germany). After removal, the pancreas was incubated for $20 \mathrm{~min}$ at $37^{\circ} \mathrm{C}$ and, subsequently, washed three times in Hanks balanced salts solution. This procedure yields about 100-200 islets per pancreas. Islets were then handpicked under a stereo microscope and cultured overnight in RPMI 1640 medium, supplemented with $10 \%$ fetal calf serum, $2.06 \mathrm{mmol} / 1 \mathrm{~L}$-glutamine, $100 \mathrm{IU} / \mathrm{ml}$ streptomycin, and $100 \mathrm{IU} / \mathrm{ml}$ penicillin at $37^{\circ} \mathrm{C}$ in an atmosphere of humidfied air equilibrated with $5 \% \mathrm{CO}_{2}$.

Batch incubations. After overnight culture, the islets were washed three times and pre-incubated for $60 \mathrm{~min}$ at $37^{\circ} \mathrm{C}$ in a Hepes buffer ( $\mathrm{pH} 7.35$ ) supplemented with $0.1 \%$ human serum albumin and $3.3 \mathrm{mmol} / \mathrm{l}$ glucose. The buffer consisted of (in $\mathrm{mmol} / \mathrm{l}$ ) $125 \mathrm{NaCl}, 5.9 \mathrm{KCl}, 1.2 \mathrm{MgCl}_{2}, 1.28 \mathrm{CaCl}_{2}$ and 25 Hepes. After the pre-incubation, single islets were transferred into new chambers (Microwell Module F-8, Immunoquality, Medium binding capacity; Nunc, Roskilde, Denmark), containing $0.1 \mathrm{ml}$ of the Hepes medium supplemented according to the protocols, and incubated, as described previously [17].

For studying the effects of PYY on insulin secretion, the Hepes buffer was supplemented with glucose $(5.6,8.3$ or $11.1 \mathrm{mmol} / 1)$, PYY $(0.1 \mathrm{nmol} / \mathrm{l}-1 \mu \mathrm{mol} / \mathrm{l})$, the phorbol ester TPA $(0.1 \mu \mathrm{mol} / \mathrm{l})$ or dibutyryl cyclic AMP $(1 \mathrm{mmol} / 1)$ according to the protocols. The single islets were incubated for $60 \mathrm{~min}$ at $37^{\circ} \mathrm{C}$, whereafter $25 \mu \mathrm{l}$ of the incubation medium was collected from each chamber and stored at $-20^{\circ} \mathrm{C}$ for determination of its insulin immunoreactivity.
Measurements of islet $C A M P$ content. For the studies on islet cyclic AMP content, 20 isolated and overnight-cultured islets were incubated for $30 \mathrm{~min}$ in glass vials containing $0.2 \mathrm{ml}$ of the Hepes buffer, as described previously [18]. The Hepes medium was supplemented with 1.8 or $11.1 \mathrm{mmol} / \mathrm{l}$ glucose with or without the addition of PYY $(1 \mathrm{nmol} / \mathrm{l})$. As a control, incubations with the adenylate cyclase activator forskolin $(1 \mu \mathrm{mol} / \mathrm{l})$ were also included. After the incubation period, cyclic AMP was extracted by adding ice cold trichloracetic acid to the vials, which were then rapidly frozen to $-70^{\circ} \mathrm{C}$. After thawing, the islets were centrifuged at $2000 \mathrm{~g}$ for $15 \mathrm{~min}$. The supernatant was discarded and washed four times in water-saturated diethyl ether, and then the samples were lyophilized. Thereafter, the samples were diluted in assay buffer and the cyclic AMP content was determined after acetylation of the samples using a rabbit anti-succinyl cyclic AMP serum and cyclic 2-Osuccinyl-3- $\left.-{ }^{125} \mathrm{I}\right]$ methyl ester as tracer and cyclic AMP as standard (Amersham Inc., Amersham, Bucks., UK).

Perifusion experiments. After overnight culture, islets were washed in the Hepes buffer. Thereafter, 200 islets were transferred to a chamber containing $500 \mu l$ Krebs ringer supplemented with $3.3 \mathrm{mmol} / \mathrm{l}$ glucose and $40-170 \mu \mathrm{Ci}{ }^{86} \mathrm{RbCl}$ (added from a stock solution with the initial specific activity of 1.6$6.4 \mathrm{mCi} / \mathrm{mg}$ ), and incubated in this medium for $90 \mathrm{~min}$ at $37^{\circ} \mathrm{C}$.

After labelling and washing in the Hepes buffer, groups of 50 islets were transferred to perifusion columns where they were sandwiched between two layers $(200 \mu \mathrm{l})$ of gel (Bio-gel P 4, 200-400 mesh, Bio-Rad Lab., Richmond, Calif., USA) as described previously [17]. The islets were perifused at a flow rate of $100 \mu \mathrm{l} / \mathrm{min}$, at $37^{\circ} \mathrm{C}$. After $20 \mathrm{~min}$ of pre-perifusion with the Hepes buffer containing $11.1 \mathrm{mmol} / \mathrm{l}$ glucose, the perifusate was collected at 2 -min intervals for $80 \mathrm{~min}$. Twenty min after the pre-perifusion period, PYY ( $1 \mathrm{nmol} / 1)$ was introduced to the perifusion medium for a further $20 \mathrm{~min}$. Controls perifused with $11.1 \mathrm{mmol} / \mathrm{l}$ glucose alone were included in each separate experiment. The $\mathrm{K}^{+}$-channel opener, diazoxide $(400 \mu \mathrm{mol} / 1)$, was added to all columns at the end of each perifusion period as a positive control. In the experiments performed under $\mathrm{Ca}^{2+}$-deficient conditions, the perifusion medium was supplemented with $0.5 \mathrm{mmol} / \mathrm{l}$ EGTA (British Drug Houses Ltd., Poole, Dorset, UK). From each sample, $25 \mu 1$ was removed for determination of insulin immunoreactivity, and $100 \mu \mathrm{l}$ was removed and added to $5 \mathrm{ml}$ of scintillation fluid (Ready SafeT; Beckman Instruments Inc., Fullerton, Calif., USA) for liquid scintillation counting (Packard Instrument Inc., Downers Grove, Ill., USA).

Insulin analysis. The concentration of insulin was determined with a radioimmunoassay, using a guinea-pig anti-rat insulin antibody (Linco Research, St. Louis, Mo., USA), ${ }^{125}$ I-labelled porcine insulin (Novo Research, Bagsvaerd, Denmark) as a tracer, and rat insulin (Linco) as a standard. The bound antibody-antigen complex was precipitated through the use of an anti-IgG (goat anti-guinea pig) antibody (Linco).

Studies on the cytoplasmic $\mathrm{Ca}^{2+}$ concentration. The cytoplasmic $\mathrm{Ca}^{2+}$ concentration was measured in islet cell suspensions as described previously [19]. Overnight cultured islets were washed three times in fresh culture medium. Thereafter approximately 1200 islets were mechanically disrupted with a Pasteur pipette in a $\mathrm{Ca}^{2+}$ and $\mathrm{Mg}^{2+}$-free phosphate buffered saline-Dulbecco solution (Biochrom KG, Berlin, Germany), which was supplemented with $0.025 \%$ trypsin (Gibco BRL, Paisley, Scotland) and $0.05 \%$ EDTA (Versen, Biochrom). The cells were then resuspended in RPMI 1640 medium and gently shaken for $2 \mathrm{~h}$ at $37^{\circ} \mathrm{C}$ in humified air equilibrated with $5 \%$ 


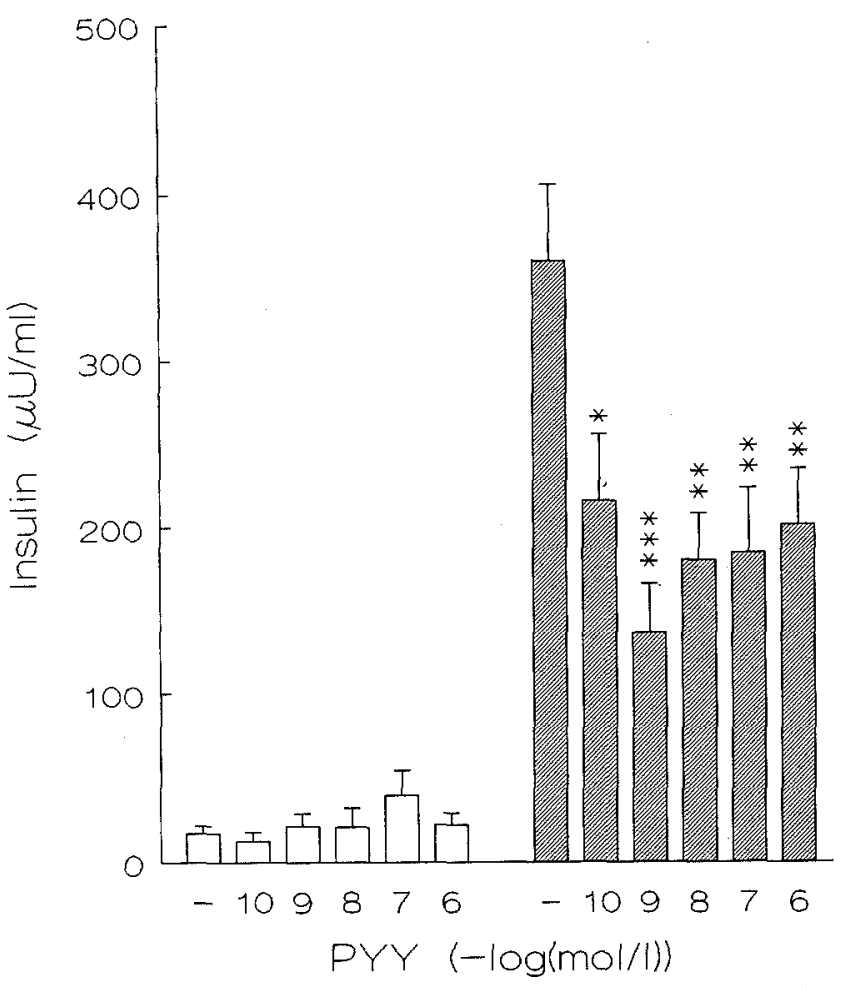

Fig. 1. Effect of PYY on glucose-stimulated insulin secretion from isolated mouse islets. Islets were incubated for $60 \mathrm{~min}$ at

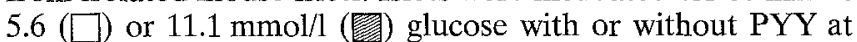
0.1 to $1 \mu \mathrm{mol} / 1$. Probability level of random difference in insulin secretion from islets incubated at $11.1 \mathrm{mmol} / \mathrm{l}$ glucose in the presence vs in the absence of PYY; ${ }^{*}$ " $p<0.001$; ${ }^{* *} p<0.01 ;^{*} p<0.05(n=22-44$ in each group)

$\mathrm{CO}_{2}$. This procedure yields cell suspensions consisting of single cells and clusters of up to 20 cells. The cell viability in these suspensions as measured by trypan blue staining is above $98 \%$. After $2 \mathrm{~h}$, FURA 2-AM (10 $\mu \mathrm{mol} / \mathrm{l}$; Sigma) was added to the cell suspension and loaded for $45 \mathrm{~min}$. The cell suspension was thereafter rinsed in the Hepes buffer and gently shaken for a further $20 \mathrm{~min}$ in order to allow equilibration of the $\mathrm{Ca}^{2+}$ concentration of the islet cells. After resuspension in $2 \mathrm{ml}$ of fresh Hepes buffer, the cell suspension was transferred to a cuvette in a Perkin-Elmer LS50 spectrofluorometer for measurement of cytoplasmic $\mathrm{Ca}^{2+}$ concentrations. The excitation wavelengths were 340 and $380 \mathrm{~nm}$ and the emission wavelength was $490 \mathrm{~nm}$. The various test substances were added in small volumes according to the protocols. PYY was added at concentrations from $1-100 \mathrm{nmol} / 1$ and as control, (in $\mathrm{mmol} / \mathrm{l}$ ) 0.1 carbachol, 15 glyceraldehyde, $32.5 \mathrm{KCl}$, and the $\mathrm{Ca}^{2+}$-channel blocking agent D-600 (5 $\mu \mathrm{mol} / \mathrm{l})$ were used. Fluorescence maximum was obtained by adding $0.03 \%$ triton and fluorescence minimum by adding EGTA in excess (British Drug Houses Ltd.). The cytoplasmic $\mathrm{Ca}^{2+}$ concentration was calculated according to the formula initially described by Grynkiewics et al. [20]. $\mathrm{K}_{\mathrm{d}}$ was assumed to be $224 \mathrm{nmol} / \mathrm{l}$.

\section{Statistical analysis}

The results are given as means $\pm \mathrm{SEM}$. The data from the perifusion experiments are presented as the fractional outflow of ${ }^{86} \mathrm{Rb}^{+}$from the islets, as calculated for each time

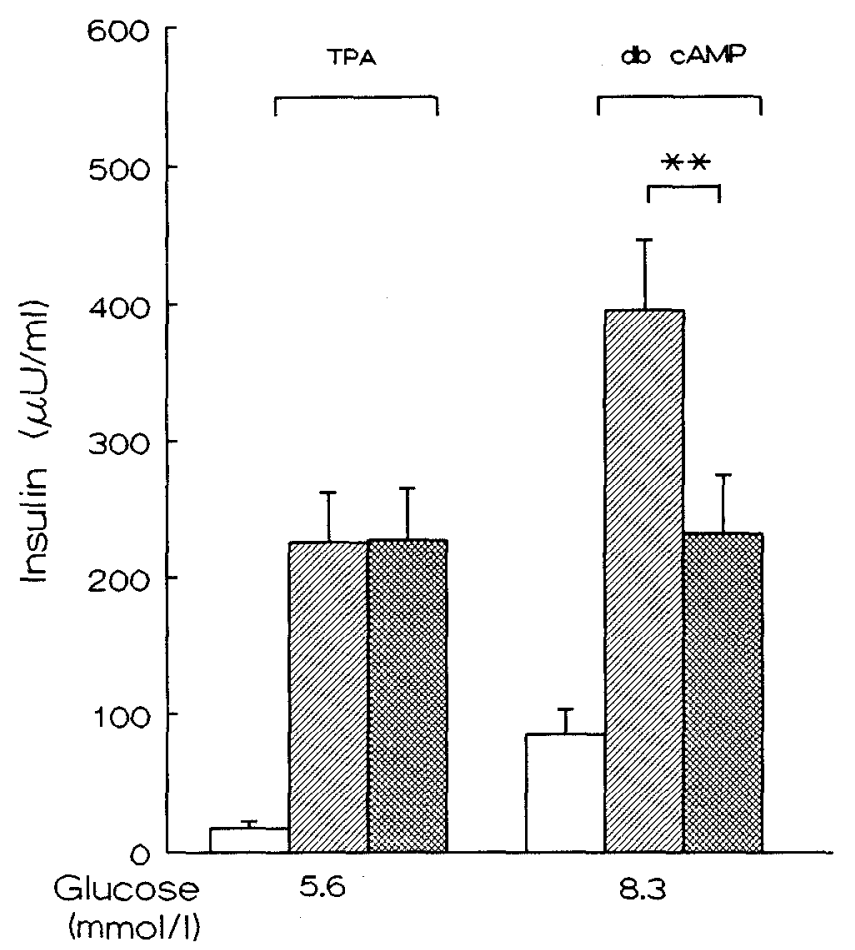

Fig. 2. Effects of PYY $(1 \mathrm{nmol} / \mathrm{l})$ on TPA $(0.1 \mu \mathrm{mol} / \mathrm{l})$ - and dibutyryl cyclic AMP (1 mmol/1)-stimulated insulin secretion from isolated mouse islets incubated for $60 \mathrm{~min}$ in the presence of 5.6 or $8.3 \mathrm{mmol} / \mathrm{l}$ glucose. Islets were incubated together with TPA $(0.1 \mathrm{mmol} / \mathrm{l})$ or dibutyryl cyclic AMP (dbcAMP, $1 \mathrm{mmol} / \mathrm{l}$ ) in the absence ( 7 ) or in the presence ( ) PY (1 nmol/l). Controls with glucose alone $(\square)$. Probability level of random difference in insulin secretion from islets between the experimental groups as indicated in the figure, ${ }^{* *} p<0.01,(n=44-45$ in each group $)$

point, and the degree of statistical significance was calculated by two-way analysis of variance (ANOVA). Student's unpaired $t$-test was used for statistical analysis of the batch incubation experiments, and the probability levels of random difference are given. The results from the FURA-2AM experiments are reported as one typical trace out of five different cell preparations.

\section{Results}

Effects of PYY on basal and glucose-stimulated insulin secretion. At a glucose concentration of $11.1 \mathrm{mmol} / 1$, PYY significantly inhibited glucose-stimulated insulin secretion, with a maximal inhibition (of approximately $71 \%$ ) observed at $1 \mathrm{nmol} / 1$ $(p<0.001)$. Higher dose levels $(10 \mathrm{nmol} / 1-1 \mu \mathrm{mol} / \mathrm{l})$ did not further inhibit insulin secretion. In contrast, PYY was without effect on insulin secretion at $5.6 \mathrm{mmol} / 1$ glucose (Fig. 1) or at $8.3 \mathrm{mmol} / 1$ glucose $(20 \pm 4$ vs $13 \pm 4 \mu \mathrm{U} / \mathrm{ml}, n=8$, NS, data not shown in Fig. 1). Thus, PYY was found to inhibit glucose-stimulated insulin secretion from mouse pancreatic islets, whereas no effect was observed at low, substimulatory, glucose concentrations. 

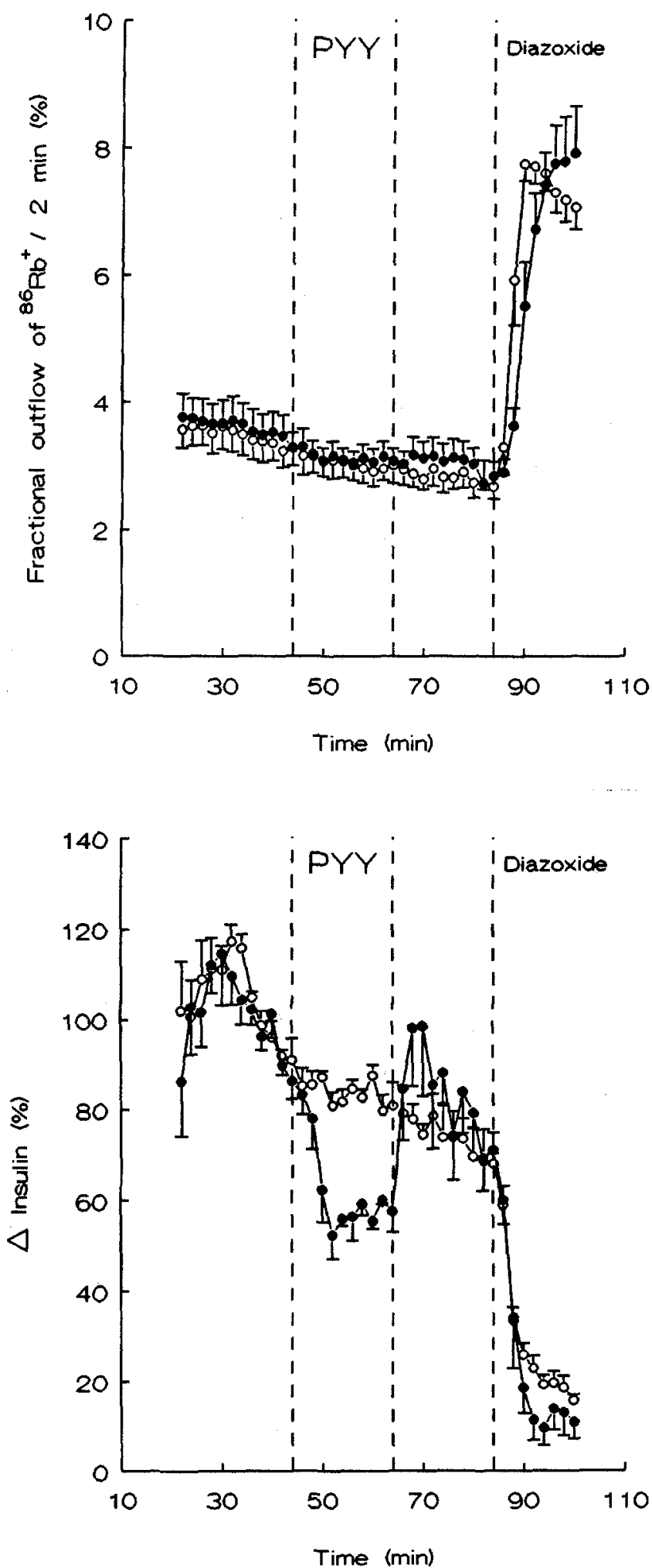

Fig. 3. Effects of PYY ( $1 \mathrm{nmol} / \mathrm{l})$ on the fractional outflow of ${ }^{86} \mathrm{Rb}^{+}$(upper panel) and insulin release (lower panel) from perifused ${ }^{86} \mathrm{Rb}^{+}$-pre-labelled mouse islets. The absolute insulin values during the 2 -min period before the introduction of PYY were $144 \pm 25 \mu \mathrm{U} / \mathrm{ml}$. The perifusion medium contained $11.1 \mathrm{mmol} / 1$ glucose throughout the perifusion period; PYY $(1 \mathrm{nmol} / 1)$ and diazoxide $(400 \mu \mathrm{mol} / \mathrm{l})$ were added as indicated. Columns to which PYY (1 nmol/l) was added (- - -$)$; Control columns ( - -) ( $n=4$ in both groups)
Effects of PYY on TPA- and dibutyryl cyclic AMP-stimulated insulin secretion. At $5.6 \mathrm{mmol} / 1$ glucose, exposure of islets to the phorbol ester TPA $(0.1 \mu \mathrm{mol} / \mathrm{l})$ stimulated insulin release from $14 \pm 4$ to 226 $\pm 36 \mu \mathrm{U} / \mathrm{ml}(p<0.001)$. PYY $(1 \mathrm{nmol} / \mathrm{l})$ did not affect this TPA-induced insulin secretion $(226 \pm 36$ vs $228 \pm 38 \mu \mathrm{U} / \mathrm{ml}$, NS). Dibutyryl cyclic AMP $(1 \mathrm{mmol} / \mathrm{l})$, at $8.3 \mathrm{mmol} / \mathrm{l}$ glucose, increased insulin secretion from $86 \pm 18$ to $396 \pm 51 \mu \mathrm{U} / \mathrm{ml}, p<0.01$ ). PYY (1 nmol/1) inhibited the dibutyryl cyclic AMPstimulated insulin secretion from $396 \pm 51$ to 232 $\pm 43 \mu \mathrm{U} / \mathrm{ml}(p<0.01)$. Taken together, these results indicate that PYY inhibits insulin secretion by a mechanism not related to $\mathrm{PKC}$ activation but rather related to inhibition of the action of cyclic AMP.

Effects of PYY on ${ }^{86} R b^{+}$efflux in the presence of extracellular $\mathrm{Ca}^{2+}$. At a glucose concentration of $11.1 \mathrm{mmol} / \mathrm{l}$, administration of PYY $(1 \mathrm{nmol} / \mathrm{l}) \mathrm{did}$ not affect the fractional outflow of ${ }^{86} \mathrm{Rb}^{+}$from pre-labelled islets (Fig. 3, upper panel), although the peptide caused a concomitant suppression of insulin secretion from the same islets $(p<0.001$; Fig. 3, lower panel). This suppression of insulin secretion started immediately after the addition of PYY, and lasted until PYY was withdrawn from the perifusion medium. The $\mathrm{K}^{+}$-channel-opener diazoxide $(400 \mu \mathrm{mol} / \mathrm{l})$, which was added as a positive control at the end of each experiment, was found to increase the ${ }^{86} \mathrm{Rb}^{+}$efflux and, at the same time, to decrease insulin release $(p<0.001)$. Thus, under conditions where PYY inhibited insulin secretion, the peptide was without effect on ${ }^{86} \mathrm{Rb}^{+}$efflux, indicating that PYY does not inhibit insulin secretion by increasing the $\mathrm{K}^{+}$permeability.

Effects of PYY on ${ }^{86} R b^{+}$efflux in the absence of extracellular $\mathrm{Ca}^{2+}$. In order to eliminate the contribution of $\mathrm{Ca}^{2+}$-activated $\mathrm{K}^{+}$channels to the ${ }^{86} \mathrm{Rb}^{+}$efflux, experiments with $\mathrm{PYY}$ were performed in the absence of extracellular $\mathrm{Ca}^{2+}$. It was thereby found that PYY $(1 \mathrm{nmol} / 1)$ caused a small but significant increase in the fractional outflow of ${ }^{86} \mathrm{Rb}^{+}(p<0.001$; Fig. 4). This increase occurred immediately after addition of PYY, but lasted for only 12 min although PYY was present in the perifusion medium for a further $8 \mathrm{~min}$ (Fig. 4, lower panel). Addition of diazoxide $(400 \mu \mathrm{mol} / 1)$ to the perifusion medium increased the fractional outflow of ${ }^{86} \mathrm{Rb}^{+}$from the islets $(p<0.001$; Fig. 4, upper panel).

Effects of PYY on islet cyclic AMP content (Table 1). The cyclic AMP content of islets incubated at $11.1 \mathrm{mmol} / \mathrm{l}$ glucose was significantly increased compared to islets incubated at $1.8 \mathrm{mmol} / 1$ glucose (31 \pm 2 vs $22 \pm 3 \mathrm{fmol} /$ islet, $p<0.05)$. At $1.8 \mathrm{mmol} / 1 \mathrm{glu}-$ cose, PYY $(1 \mathrm{nmol} / 1)$ did not affect the islet cyclic AMP content. In contrast, at $11.1 \mathrm{mmol} / \mathrm{l}$ glucose, PYY $(1 \mathrm{nmol} / \mathrm{l})$ caused a significant decrease in the 

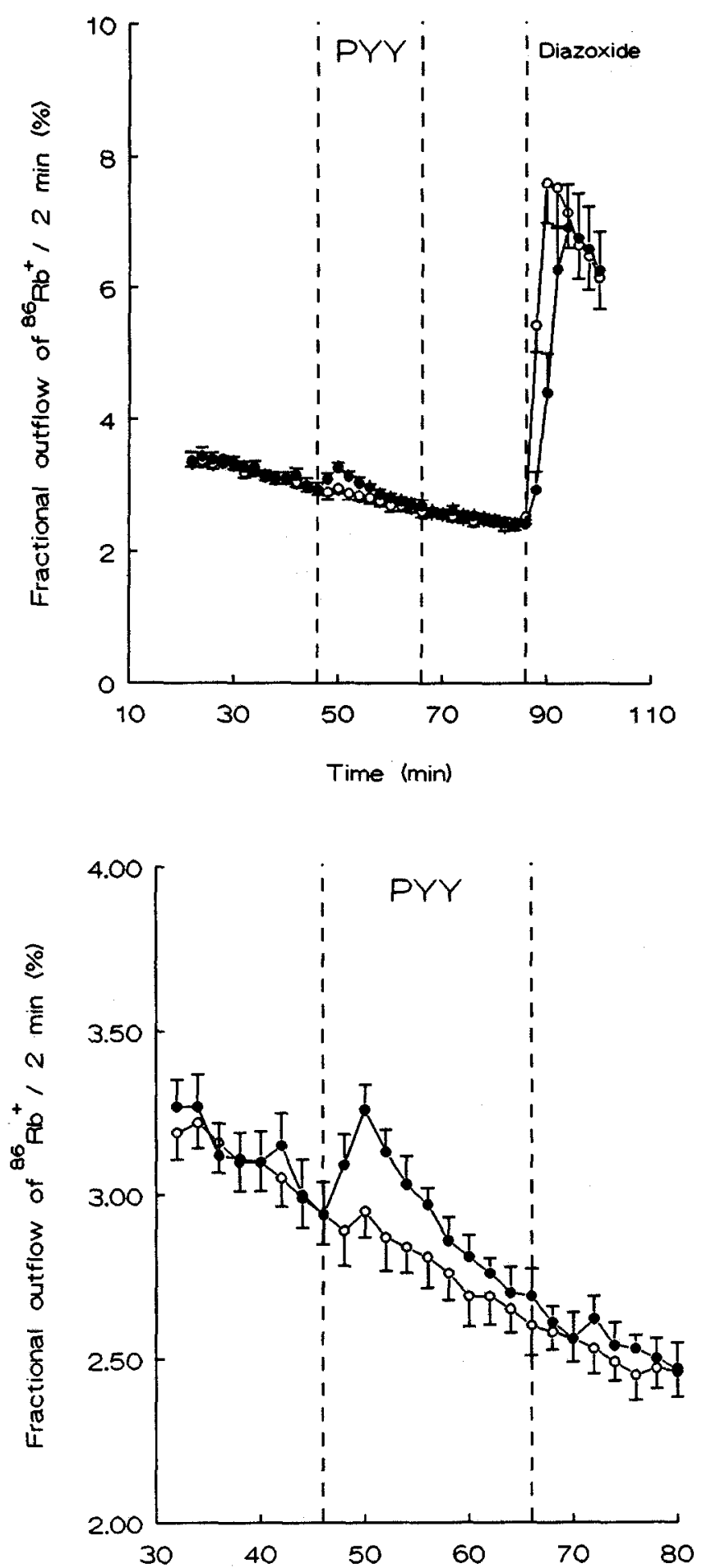

Fig. 4. Effects of $1 \mathrm{nmol} / 1 \mathrm{PYY}$ on the fractional outflow of ${ }^{86} \mathrm{Rb}^{+}$from perifused ${ }^{86} \mathrm{Rb}^{+}$-pre-labelled mouse islets, in a $\mathrm{Ca}^{2+}$-deficient perifusion medium to which $0.5 \mathrm{mmol} / \mathrm{l}$ EGTA was added. The perifusion medium contained $11.1 \mathrm{mmol} / \mathrm{lglu}-$ cose throughout the perifusion period; $1 \mathrm{nmol} / 1 \mathrm{PYY}$ and $400 \mu \mathrm{mol} / 1$ diazoxide were added as indicated in the figure. Columns to which PYY $(1 \mathrm{nmol} / \mathrm{l})$ was added (- -$)$; Control columns $\left(-\mathrm{O}^{-}\right)$( $n=7$ in both groups). Lower panel is a magnification from time point 30 to $80 \mathrm{~min}$
Table 1. Effects of PYY on islet cyclic AMP content

\begin{tabular}{ll}
\hline Substance & $\begin{array}{l}\text { Cyclic AMP } \\
\text { (fmol/islet) }\end{array}$ \\
\hline $1.8 \mathrm{mmol} / 1$ glucose & $22 \pm 3$ \\
$1.8 \mathrm{mmol} / 1$ glucose + PYY $(1 \mathrm{nmol} / \mathrm{l})$ & $18 \pm 4$ \\
$11.1 \mathrm{mmol} / 1$ glucose & $31 \pm 2^{\mathrm{a}}$ \\
$11.1 \mathrm{mmol} / \mathrm{lg}$ glucose $+\mathrm{PYY}(1 \mathrm{nmol} / \mathrm{l})$ & $21 \pm 3^{\mathrm{b}}$ \\
$1.8 \mathrm{mmol} / \mathrm{lglucose}+$ forskolin $(1 \mu \mathrm{mol} / \mathrm{l})$ & $117 \pm 16^{\mathrm{c}}$ \\
\hline
\end{tabular}

Islets were incubated for $30 \mathrm{~min}$ at 1.8 or $11.1 \mathrm{mmol} / \mathrm{l}$ glucose in the absence or in the presence of PYY $(1 \mathrm{nmol} / 1)(n=3-4$ in each group). ${ }^{\mathrm{a}} p<0.05$ vs $1.8 \mathrm{mmol} / 1$ glucose, ${ }^{\mathrm{b}} p<0.05$ vs $11.1 \mathrm{mmol} / 1$ glucose without PYY, ${ }^{\mathrm{c}} p<0.01$ vs $1.8 \mathrm{mmol} / 1 \mathrm{glu}-$ cose

islet cyclic AMP content $(p<0.05)$, indicating that PYY under conditions during which it inhibits glucose-stimulated insulin secretion, the peptide also reduces the islet concentration of cyclic AMP. Addition of the adenylate cyclase-activator forskolin $(1 \mu \mathrm{mol} / \mathrm{l})$, added as a control, markedly raised the islet cyclic AMP content $(p<0.01)$.

Effects of PYYon the cytoplasmic $\mathrm{Ca}^{2+}$ concentration. At $11.1 \mathrm{mmol} / 1$ glucose, PYY, at concentrations ranging from 1 to $100 \mathrm{nmol} / 1$, was without effect on the cytoplasmic $\mathrm{Ca}^{2+}$ concentration in dispersed mouse islet cells. Added as a control in the same experiments, carbachol $(0.1 \mathrm{mmol} / \mathrm{l})$ markedly increased the cytoplasmic $\mathrm{Ca}^{2+}$ concentration in a biphasic manner. Also, glyceraldehyde $(15 \mathrm{mmol} / 1)$ and $\mathrm{KCl}$ (32.5 mmol/1) increased the cytoplasmic $\mathrm{Ca}^{2+}$ concentration, whereas it was markedly reduced by addition of the $\mathrm{Ca}^{2+}$ channel blocking agent D-600. Thus, under conditions in which PYY inhibits insulin secretion, the peptide is without effect on the cytoplasmic $\mathrm{Ca}^{2+}$ concentration.

\section{Discussion}

Previous studies have shown that PYY inhibits insulin release both in vivo [8-11], and in vitro [12]. The present study provides further evidence for a direct islet action of this peptide, since a clear-cut inhibition of insulin secretion was observed in perifused mouse islets. Furthermore, this study suggests that the mechanism behind the insulinostatic effect of PYY involves inhibition of both the accumulation and the action of cyclic AMP.

It is known that the ATP-regulated K-channels are of importance in beta-cell signal transduction [13, 14, 21]. For example, glucose closes these channels which leads to depolarization and opening of voltage-dependent $\mathrm{Ca}^{2+}$ channels and initiation of the exocytosis [14]. Some insulinostatic peptides, for example somatostatin, have been suggested to inhibit insulin secretion by opening these channels and there- 


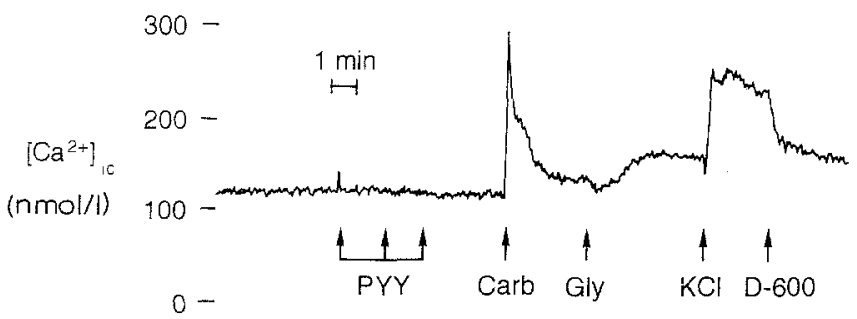

Fig. 5. Effects of PYY (1-100 nmol/l) on the cytoplasmic $\mathrm{Ca}^{2+}$ concentration in dispersed cells from isolated mouse pancreatic islets. Also the effects of carbachol (Carb, $0.1 \mathrm{mmol} / \mathrm{l})$, Glyceraldehyde (Gly, $15 \mathrm{mmol} / \mathrm{l}), \mathrm{KCl}(32.5 \mathrm{mmol} / \mathrm{l})$ and D-600 $(5 \mu \mathrm{mol} / 1)$ are shown. Representative trace out of five different islet cell preparations. Different test substances were administered as indicated

by hyperpolarize the beta cell and lower the cytoplasmic $\mathrm{Ca}^{2+}$ concentration [22]. We also examined whether the insulinostatic effect of PYY is due to such an action by the use of ${ }^{86} \mathrm{Rb}^{+}$pre-loaded islets, since the subsequent ${ }^{86} \mathrm{Rb}^{+}$efflux from such islets represents the degree of $\mathrm{K}^{+}$permeability $[23,24]$. We found, however, that PYY was without effect on ${ }^{86} \mathrm{Rb}^{+}$efflux from pre-labelled mouse islets in the presence of extracellular $\mathrm{Ca}^{2+}$, despite the fact that the peptide inhibited glucose-stimulated insulin secretion from the very same islets. This suggests that the inhibition by PYY of insulin secretion is not mediated by increased $\mathrm{K}^{+}$-permeability, since such an action would have increased the ${ }^{86} \mathrm{Rb}^{+}$efflux, as was observed by diazoxide, which inhibits insulin secretion by opening the ATP-regulated $\mathrm{K}^{+}$channels $[25,26]$.

In a $\mathrm{Ca}^{2+}$-deficient medium, however, PYY induced a slight and transient increase in the ${ }^{86} \mathrm{Rb}^{+}$efflux. It should be emphasized that the ${ }^{86} \mathrm{Rb}^{+}$efflux from pre-labelled islets represents the sum of the activity of all plasma membrane $\mathrm{K}^{+}$channels, i.e., not only the ATP-regulated but also $\mathrm{Ca}^{2+}$ - and voltagedependent $\mathrm{K}^{+}$channels. Our results could be interpreted as if PYY indeed has the ability to increase the $\mathrm{K}^{+}$permeability, for example by opening the ATP-regulated $\mathrm{K}^{+}$channels, but that this is not seen in the presence of extracellular $\mathrm{Ca}^{2+}$ due to a concomitantly reduced activity of the $\mathrm{Ca}^{2+}$ and/or voltage-dependent $\mathrm{K}^{+}$-channels [27]. An increased $\mathrm{K}^{+}$ permeability through the opening of ATP-regulated $\mathrm{K}^{+}$-channels could thus, due to hyperpolarization of the plasma-cell membrane, lower the cytoplasmic $\mathrm{Ca}^{2+}$ concentration and thereby restrain the activity of the $\mathrm{Ca}^{2+}$-activated $\mathrm{K}^{+}$channels. However, such a mechanism seems less likely since we repeatedly found that PYY was without effect on the cytoplasmic $\mathrm{Ca}^{2+}$ concentration, as measured by the FURA 2-AM technique in dispersed mouse islet cells. It is therefore concluded that the mechanism behind the insulinostatic effect of PYY does not involve increased $\mathrm{K}^{+}$permeability or lowering of the cytoplasmic $\mathrm{Ca}^{2+}$ concentration.
The mechanism by which PYY increases the fractional outflow of ${ }^{86} \mathrm{Rb}^{+}$from isolated mouse pancreatic islets in the absence of extracellular $\mathrm{Ca}^{2+}$ is thus not clear. Previously, it has been shown in other tissues, i.e., in Aplysia sensory neurons, that activation of the cyclic AMP cascade reduces certain $\mathrm{K}^{+}$currents [28]. Although this has not been reported for islet beta cells, the increase in ${ }^{86} \mathrm{Rb}^{+}$efflux could, theoretically, result from the restraining effect of PYY on the accumulation and action of cyclic AMP. On the other hand, such a hypothesis is contradicted by a previous study, in mouse beta cells, which showed an increased $\mathrm{K}^{+}$-permeability after increasing the cellular cyclic AMP content by forskolin at a stimulatory glucose level [29].

PYY is known to exert its effects, in other tissues, through acting on at least three subtypes of a generic neuropeptide Y/PYY receptor, i.e., the $\mathrm{Y}_{1}, \mathrm{Y}_{2}$ and $\mathrm{Y}_{3}$ subreceptors $[30,31]$. In a recent study in a conscious dog, the PYY-receptor subtype involved in the inhibitory effect of PYY on 2-deoxy-D-glucose-induced insulin secretion was suggested to be of the $Y_{1^{-}}$ subtype [32]. The subtype of receptor involved in the inhibitory effect of PYY on insulin secretion under in vitro conditions in mouse islets cannot be deduced from the present study, since adenylate cyclase inhibition is a known feature of all three neuropeptide $\mathrm{Y}$ / PYY receptor subtypes $[30,31]$, and in the present study, PYY was found to reduce glucose-stimulated cyclic AMP accumulation. The characterization of the PYY receptor subtype involved in the inhibitory effect of PYY on insulin secretion under in vitro conditions has therefore to await further studies.

In addition to inhibiting cyclic AMP accumulation in mouse pancreatic islets, PYY also seems to inhibit the action of cyclic AMP, since the peptide inhibited dibutyryl cyclic AMP-stimulated insulin secretion. Thus, PYY seems to exert an inhibitory effect on the cyclic AMP system in islets by acting at two consecutive steps in the intracellular cyclic AMP cascade. Furthermore, PYY was found to be without effect on insulin secretion induced by the PKC-activating agent TPA. This shows that the peptide is not an inhibitor of protein kinase $\mathrm{C}$ or an inhibitor of the exocytosis process itself, but rather has a specific inhibitory effect on the cyclic AMP system within the pancreatic beta cell. Interestingly, PYY has previously been demonstrated to inhibit insulin secretion stimulated by the insulinotropic hormone gastric inhibitory polypeptide in the dog [11], and formation of cAMP is a mechanism behind the insulinotropic effect of GIP [33].

Plasma levels of PYY have previously been shown to increase within an hour after food intake in humans (from approximately 8 to $45 \mathrm{pmol} / \mathrm{l}$ ) and in the dog (from approximately 200 to $400 \mathrm{pmol} / \mathrm{l}$ ) $[34,35]$. In the dog, PYY inhibits stimulated insulin secretion at concentrations within this range $[10$, 
11]. This suggests a possible endocrine role for PYY, at least in the dog. Whether PYY also inhibits stimulated insulin secretion in man is not known. Under basal conditions PYY does not affect plasma insulin levels in man [36]. In addition to a possible endocrine role of PYY, the co-localization of PYY and glucagon within the same secretory granules of the pancreatic alpha cell $[6,7]$ suggests that PYY might also act as a paracrine modulator of insulin secretion. Under the conditions used in the present experiments a possible release of PYY from the alpha cells is, however, probably negligible, since we used a high glucose concentration, which inhibits alphacell secretion.

In conclusion, PYY inhibits glucose-stimulated insulin secretion by a direct effect on the pancreatic beta cell possibly by interacting with two different steps in the cyclic AMP cascade, and thereby interacting with the accumulation as well as with the action of cyclic AMP.

Acknowledgements. The technical assistance of Ms. L. Kvist and Ms. L. Bengtsson is gratefully acknowledged. The study was financially supported by The Swedish Medical Research Council (grants no. 14X-6834 and 12X-712); Nordisk Insulinfond; Swedish Diabetes Association; The Swedish Society of Medicine; Craafordska and Albert Påhlssons Foundations; and by the Faculty of Medicine, Lund University, Lund, Sweden.

\section{References}

1. Taylor IL (1989) Peptide YY: the ileo-colonic, gastric, and pancreatic inhibitor. Biol Bull 177: 187-191

2. Böttcher G, Ekblad E, Ekman R, Håkanson R, Sundler F (1993) Peptide YY: a neuropeptide in the gut. Immunocytochemical and immunochemical evidence. Neuroscience 55: $281-290$

3. Tatemoto K, Carlquist M, Mutt V (1982) Neuropeptide Y a novel brain peptide with structural similarities to peptide YY and pancreatic polypeptide. Nature 296: 659-660

4. Ahrén B, Östenson CG, Efendic S (1991) Other islet peptides. In: Samols E (ed) The endocrine pancreas. Raven Press, New York, pp 153-173

5. Petterson M, Ahrén B (1990) Insulin secretion in rats: effects of neuropeptide $\mathrm{Y}$ and noradrenaline. Diabetes Res 13: $35-42$

6. Böttcher G, Sjöberg J, Ekman R, Håkanson R, Sundler F (1993) Peptide YY in the mammalian pancreas: immunocytochemical localization and immunochemical characterization. Regul Pept 43: 115-130

7. Böttcher G, Ekman R, Lundqvist G, Ahrén B, Sundler F (1994) Pancreatic peptide $\mathrm{YY}$ in alloxan diabetic mice. Pancreas (in press)

8. Böttcher G, Ahrén B, Lundquist I, Sundler F (1989) Peptide YY: intrapancreatic localization and effects on insulin and glucagon secretion in the mouse. Pancreas 4: 282--288

9. Szecowka J, Tatemoto K, Rajamäki G, Efendic S (1983) Effects of PYY and PP on endocrine pancreas. Acta Physiol Scand 119: 123-126

10. Greeley GH, Lluis F, Gomez G, Ishizuka J, Holland B, Thompson JC (1988) Peptide YY antagonizes $\beta$-adrener- gic-stimulated release of insulin in dogs. Am J Physiol 254: E513-E517

11. Guo YS, Singh P, Draviam E, Greeley GH, Thompson JC (1989) Peptide YY inhibits the insulinotropic action of gastric inhibitory polypeptide. Gastroenterology 96: 690-694

12. Bertrand G, Gross R, Roye M, Ahrén B, Ribes G (1992) Evidence for a direct inhibitory effect of PYY on insulin secretion in rats. Pancreas 7: 595-600

13. Prentki M, Matschinsky FM (1987) $\mathrm{Ca}^{2+}$, cAMP, and phospholipid-derived messengers in coupling mechanisms of insulin secretion. Physiol Rev 67: 1185-1248

14. Rajan AS, Aguilar-Bryan L, Nelson DA et al. (1990) Ion channels and insulin secretion. Diabetes Care 13:340--363

15. Farese RV, Standaert ML, Arnold T et al. (1992) The role of protein kinase $C$ in insulin action. Cell Signal 4: 133-143

16. Lacy PE, Kostianovski M (1967) Method for the isolation of intact islets of Langerhans from the rat pancreas. Diabetes 16: 35-39

17. Skoglund G, Lundquist I, Ahrén B (1988) Selective $\alpha$-adrenoceptor activation by clonidine: effects on ${ }^{45} \mathrm{Ca}^{2+}$ efflux and insulin secretion from isolated rat islets. Acta Physiol Scand 132: 289-296

18. Ahrén B, Karlsson S, Linskog S (1990) Cholinergic regulation of the endocrine pancreas (1990) In: Aquilonius S-M, Gillberg P-G (ed) Progress in brain research 84. Elsevier, Amsterdam pp. 209-218

19. Fridolf T, Karlsson S, Ahrén B (1992) The effects of CCK-8 on the cytoplasmic free calcium concentration in isolated rat islet cells. Biochem Biophys Res Commun 192: 878-882

20. Grynkiewics G, Poenie M, Tsien R (1985) A new generation of $\mathrm{Ca}^{2+}$ indicators with greatly improved fluorescence properties. J Biol Chem 260: 3440-3450

21. Henquin JC (1987) Regulation of insulin release by ionic and electrical events in B cells. Hormone Res 27: 168-178

22. Nilsson T, Arkhammar P, Rorsman P, Berggren PO (1989) Suppression of insulin release by galanin and somatostatin is mediated by a G-protein: an effect involving repolarization and reduction in cytoplasmic free $\mathrm{Ca}^{2+}$ concentration. J Biol Chem 264: 973-980

23. Malaisse WJ, Boschero AC, Kawazu S, Hutton JC (1978) The stimulus secretion coupling of glucose-induced insulin release. XXVII. Effects of glucose on $\mathrm{K}^{+}$fluxes in isolated islets. Pflügers Arch 373: 237-242

24. Henquin JC (1980) The potassium permeability of pancreatic islet cells: mechanisms of control and influence on insulin release. Horm Metab Res 10 [Suppl]: 66-73

25. Trube G, Rorsman P, Ohno-Shosaku T (1986) Opposite effects of tolbutamide and diazoxide on the ATP-dependent $\mathrm{K}^{+}$channel in mouse pancreatic $\beta$-cells. Pflügers Arch 407: 493-499

26. Henquin JC, Meissner HP (1982) Opposite effects of tolbutamide and diazoxide on ${ }^{86} \mathrm{Rb}^{+}$fluxes and membrane potential in pancreatic beta cells. Biochem Pharmacol 31: 1407-1415

27. Drews G, Debuyser A, Nenquin M, Henquin JC (1990) Galanin and epinephrine act on distinct receptors to inhibit insulin release by the same mechanisms including an increase in $\mathrm{K}^{+}$permeability of the B-cell membrane. Endocrinology 126: 1646-1653

28. Goldsmith BA, Abrams TW (1992) cAMP modulates multiple $\mathrm{K}^{+}$currents, increased spike duration and excitability in Aplysia sensory neurons. Proc Natl Acad Sci USA 89. 11481-11485

29. Henquin JC, Meissner HP (1984) The ionic, electrical, and secretory effects of endogenous cyclic adenosine monophosphate in mouse pancreatic B cells: studies with forskolin. Endocrinology 115: 1125-1134 
30. Michel MC (1991) Receptors for neuropeptide Y: multiple subtypes and multiple second messengers. Trends Pharmacol Sci 12: 389-394

31. Wahlestedt C, Regunathan S, Reis DJ (1991) Identification of cultured cells selectively expressing Y1-, Y2-, or Y3-type receptors for neuropeptide Y/peptide YY. Life Sci 50: 7-12

32. Yoshinaga K, Mochizuki T, Yanaihara N et al. (1992) Structural requirements of peptide $\mathrm{YY}$ for biological activity at enteric sites. Am J Physiol 263: G695-G701

33. Lu M, Wheeler MB, Leng XH, Boyd III AE (1993) The role of the free cytosolic calcium transduction by gastric inhibitory polypeptide and glucagon-like peptide I(7-36). Endocrinology 132: 94-100
34. Taylor IL (1985) Distribution and release of peptide YY in dog measured by specific radioimmunoassay. Gastroenterology 88: 731-737

35. Adrian TE, Ferri G-L, Bacarese-Hamilton AJ, Fuessls HS, Pollak JM, Bloom SR (1985) Human distribution and release of a putative new gut hormone, peptide YY. Gastroenterology 89: 1070-1077

36. Adrian TE, Sagor GR, Savage AP, Bacarese-Hamilton AJ, Hall GM, Bloom SR (1986) Peptide YY kinetics and effects on blood pressure and circulating pancreatic and gastrointestinal hormones and metabolites in man. J Clin Endocrinol Metab 63: 803-807 